\title{
A judicial dilemma: expert witness testimony in child sex abuse cases
}

BY MARY ANN MASON, PH.D., J.D.

This study first analyzes the content of 122 appellate court decisions in which expert witness testimony on the characteristics of sexually abused children is challenged. The nature of the testimony, the identity of experts, and the patterns of judicial response to this testimony are both quantitatively and qualitatively examined. The study then reviews the concerns raised by the clinical/scientific community about the validity of this behavioral syndrome testimony and the role of the therapist as expert. The gulf between the judicial community and the clinical/scientific community is addressed. Alternative forms of expert testimony that more closely meet the criteria of both communities are suggested.

Prosecutors are faced with a frustrating problem in child sex abuse cases. Often they must prove a case with no corroborative evidence, no witnesses, and a victim who is reluctant or unable to testify against the defendant. Sometimes that victim is less than five years old. Even when the victim does testify, the nature of the testimony may be halting and/or inconsistent and may completely contradict pretrial testimony.

In juvenile and family courts the evidentiary problems are similar, although the constitutional protections afforded the 
defendant are not at issue. The goal is to protect the child in a dependency action or custody dispute, rather than to prosecute the alleged abuser, but the trial judge must still rely upon a child witness, often with no corroborating evidence. While the possible outcome for the suspected abuser is not prison in this court, the stakes are high. The result could be a parent's loss of access to his or her child and a lifelong social stigma as a child molester.

To help overcome their evidentiary problems, prosecutors and juvenile and family courts rely increasingly on expert witness testimony. In addition to medical witnesses who testify as to the physical symptoms of abuse if there are any, mental health professionals-clinical psychologists, psychiatrists, and social workers-are called upon.

These mental health experts usually offer two kinds of testimony. First, they may testify, based on their experience and training, that they consider a particular child to fit the profile of a sexually abused child. To prepare for this testimony the expert interviews the child extensively, often with the help of an anatomically correct doll, notes symptoms and behavior patterns, and formulates a diagnosis. This evaluation is sometimes derived over the course of several sessions of therapy. The parents and others who have observed the child may be questioned as well. The expert may claim that the child fits the particular characteristics of a specific syndrome associated with sexually abused children, or that the child fits a looser description of characteristics often found in sexually abused children. Often the expert will not reach this conclusion directly, but will recite the characteristics of an abused child and then describe most of the same characteristics that he has observed with this particular child witness.

The second kind of expert testimony addresses only the general characteristics of a sexually abused child, but not the behavior of a particular child. With this kind of testimony, the expert, almost always a clinician, may or may not have evalu- 
ated the child and addresses general clinical patterns observed by himself and others in sexually abused children. Here also, the testimony may be presented as a specific syndrome or more loosely described as general behavioral characteristics of a sexually abused child. ${ }^{1}$

In addition to testimony regarding the characteristics of sexually abused children, a few experts also offer their opinion on the characteristics of the abuser. These opinions are not based on interviews, but rather offer sociological theories, sometimes with statistical support, on the common characteristics of abusers of children.

Behavioral syndrome testimony in child sex abuse cases has provoked serious controversy in the courts, ${ }^{2}$ with contradictory appellate court decisions as to its admissibility within the same jurisdiction. ${ }^{3}$ Although testimony regarding the characteristics of sexually abused children is quite recent (within the last 10 years), a fairly large body of appellate court decisions (122 identifiable at the time of this writing) has developed rulings on its admissibility. ${ }^{4}$ It is now possible to discern definite patterns of expert testimony that are challenged on appeal and of appellate courts' acceptance and rejection of this testimony, as was not possible with the earlier, seemingly randomly inconsistent decisions of the first few years.

The following material is organized into four parts. Part one will examine these 122 appellate cases (both criminal and civil) to investigate the nature of the expert testimony and the kind of expert delivering the testimony that the appeal courts face. Particular attention will be paid to the wide range of characteristics that are put forth by experts, and to the background and training of the experts. Part two will analyze these appellate courts' responses to the expert testimony and to the qualifications of the experts, with particular attention to patterns of judicial admission and exclusion and their relationship to evidentiary standards. Part three will examine the 
scientific status of this diagnostic category within the context of the clinical community, and also probe the role of the expert as both therapist and fact finder. Finally, part four will explore the possibility of alternative expert testimony by scientists who are researching children's eyewitness abilities with regard to memory, suggestibility, fantasy, and ability to recall at different developmental stages.

\section{Expert testimony regarding characteristics of sexually abused chlldren}

Method A keyword search of both the WeSTLAw and LExIS complete state and federal databases from 1980 to the present was undertaken and cross-checked. The keyword descriptors employed were "expert witness" and "sex abuse." All cases that dealt with adult sex abuse were eliminated, as were all cases where the expert's testimony was not an issue on appeal. Cases dealing only with expert medical testimony or with hearsay testimony were also eliminated. It should be noted that WESTLAW, because of its extensive headnotes, yielded more cases than LEXIS.

The sample of 122 cases selected by this search was coded to describe the grounds for appeal, the identity of the experts, the nature of expert testimony described, the judges' decisions, and the judges' reasons.

There are several limitations to this data set. The information is gathered only from these appellate reports. The identity of the experts and the nature of the expert testimony reported in these appellate decisions may not be an accurate representation of expert testimony at the trial court level, since most trial court decisions are not appealed or terminate with acquittals. In addition, not all the appellate court decisions describe the expert testimony presented at the trial. Nor can this data set fairly represent how often trial courts admit or exclude experts, or how they make their decisions. 
Nevertheless, this sample is representative of appellate court judges' responses and reasoning and probably fairly represents the nature of the expert testimony and the identity of the experts they must deal with on appeal. Only by examining the trial court transcripts for each of these 122 cases could the nature of the expert testimony be known for certain.

The charac- Seventy-three of the 122 appellate cases that responded to teristics challenges of expert witness testimony specified the characteristics offered by the experts in their trial court testimony. This testimony was either applied to a specific child or presented as a general description of the behavior of sexually abused children. The characteristics and the way they are labeled vary widely, and there are significant contradictions among experts.

Syndrome testimony

Many of the earlier cases label the characteristics they present as the child sex abuse accommodation syndrome (CSAAS) or some variation of that term (see Table 1), and, they often mention Roland Summit, the psychiatrist who is generally credited with formulating this syndrome to describe intrafamilial sex abuse. ${ }^{5}$ The five characteristics that Summit noted and that are still frequently mentioned, even when not identified as CSAAS, are: secrecy, helplessness, accommodation, fear of disclosure, and retraction. In later cases the term CSAAS or its variations is less frequently noted, and most experts describe their testimony generally as characteristics 
of sexually abused children. This may well be a response to the refusal of some courts to admit the CSAAS on the grounds that it lacked scientific reliability as evidenced by its exclusion from the DSM-III-R, the diagnostic manual of the American Psychiatric Association. A few of the more recent cases move away entirely from sexual abuse classifications and instead refer to the post-traumatic stress syndrome, or PTSD, which is included in the DSM-III-R. ${ }^{6}$ This testimony emphasizes the reluctance of children to report the event immediately or at all.

In this analysis of characteristics specified by the experts in their testimony, by far the largest cluster involves denial or reluctance to report that the event occurred. And yet this behavior is offered affirmatively to prove that the event did in fact occur. Delayed reporting (21), retraction/recantation (19), conflicting and inconsistent accounts (14), are all presented by the experts as characteristics of sexually abused children (see Table 2).

The anomaly of this central core of descriptors is that children are believed only when they disclose sexual abuse and disbelieved when they deny or change their stories. Their very denials strengthen the expert's belief in their abuse.

On the other hand, 15 experts testified that sexually abused children do not lie about their abuse, and six stated that consistency in accounting is characteristic of sexually abused children. There are other contradictions as well. The second largest category of descriptors deals with the child's sexual behavior. While 14 experts cite inappropriate knowledge of sex and sexual preoccupation as characteristics of an abused child, a few (six) believe naiveté and aversion to sexual matters are marks of abuse. Likewise, in two of the cases fear of men was recited as a trait of an abused child, whereas two experts testified that a desire to protect or to continue to see the abuser was consistent with abuse. In yet another contra- 


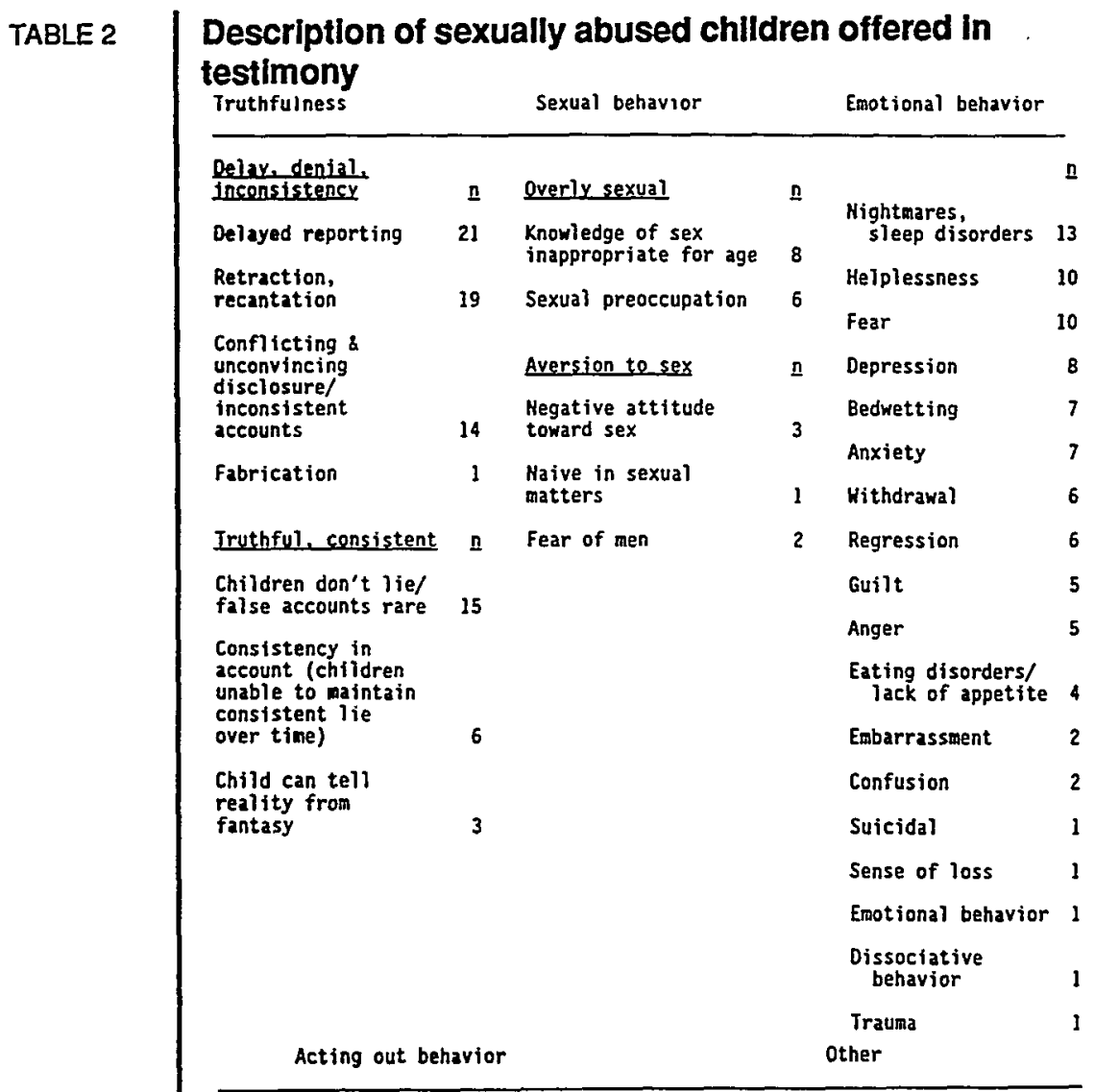

Problems at school

Aggression

Relationship problens

Running away

Pseudomaturity

Agitation
7

3

2

2

2

1 n

Play with dolls indicates

abuse

Secrecy

Accomodation

Drawings by child indicate

abuse

Inappropriate trust Ieve]

Hinimization of events

Report to non-family nember

Renember abuse occurring in

sleep

Ambivalence

Poor self-image

Restriction of activity

Sense of betrayal 
diction, pseudomaturity was cited by two experts as evidence of sexual abuse, while one expert cited emotional immaturity.

In addition, many experts described emotional or acting-out behavior consistent with sexual abuse that may be considered typical of many children at some point. These general characteristics include depression and anxiety (15), anger (5), regressive or withdrawn behavior (12), sleep or eating disorders, including nightmares and bedwetting (24), and behavioral problems such as running away, problems at school, and other forms of acting-out behavior (17).

This examination of characteristics offered by expert witnesses in this sample indicates, at the least, an imprecise behavioral profile with a number of critical contradictions. Part of the reason that these characteristics are so contradictory and diverse may be that the expert is tailoring the list to suit a particular child. For example, in State v. Myers, ${ }^{7}$ the court allowed testimony that the child was abused because she showed symptoms such as fear, confusion, poor motherdaughter relationship, fear of men, nightmares with assaultive conduct, and sexual knowledge beyond her years. On the other hand, the expert in Ward v. State ${ }^{8}$ testified that a child could show signs of abuse by sexual behavior, passiveness or aggressiveness, changes in eating habits, underachievement, sleep disturbances, or depression.

The experts Nearly all the experts have a clinical orientation, with social workers (all are L.C.S.W.s or A.C.S.W.s) the largest group, closely followed by clinical psychologists (Ph.D.s) and trailed by counselor/therapists, psychiatrists, and physicians (M.D.s). All other groups are sparsely represented (see Table 3).

Interaction of

In those instances (128) where the interaction of the expert expert with child witness with the child was noted in the appellate court decision, the great majority of experts interviewed the child $(86.7 \%)$, while a large group among those who interviewed the child (45.9\%) 
treated the child as well. Twenty-three experts specified that they employed anatomical dolls in their interview.

Most of the experts are therapists, with a significant number serving as the therapist for that particular child witness. In qualification discussions, many mentioned workshop attendance but no independent research (with the exception of Roland Summit, who is identified in three cases).

\section{Expert witness by profession}

$\begin{array}{lcr}\quad \text { Profession } & \text { n } & \% \\ \text { Social worker } & 54 & (34 \%) \\ \text { Clisical psychologist } & 49 & (31 \%) \\ \text { Counselor/therapist } & 19 & (12 \%) \\ \text { Psychiatrist } & 12 & (8 \%) \\ \text { Physician } & 12 & (8 \%) \\ \text { Other (includes professor, police } & & \\ \quad \text { investigator, school principal, etc.) } & 14 & (9 \%) \\ \text { Total } & 160 & \end{array}$

Note: There is more than one expert in many cases.

\section{Judicial response to expert testimony}

A pattern of appellate court acceptance and rejection can be identified. In the 122 cases examined, there is an overall trend in favor of admission of expert testimony (67 courts admitted testimony, 44 excluded testimony, 11 admitted in part and excluded in part). Usually these appellate courts take expert testimony at face value. They do not attempt to evaluate the content of expert testimony or to analyze its reliability. They question its acceptance by the relevant scientific community infrequently, and they rarely question the credentials of the mental health professionals who present themselves as experts.

Rather, these appellate courts are inclined to judge broadly that the testimony is helpful to the trier of fact or that it inter- 
feres with the decision-making of the trier of fact (judge or jury) to determine the credibility of the child. They are more likely to approve testimony offered on rebuttal than direct testimony. They are not inclined to create any bright-line rules for admission, and they provide little reasoned analysis.

In making their judgments, these appellate courts are guided by the Federal Rules of Evidence or their state's version of them. According to Rule 702, "If scientific, technical or other specialized knowledge will assist the trier of fact to understand the evidence or to determine a fact in issue, a witness qualified as an expert by knowledge, skill, experience, training, or education may testify thereto in the form of an opinion or otherwise." This rule is balanced by Rules 401 and 403 , which insist, respectively, that the evidence must be relevant and that it must not create a substantial likelihood of undue prejudice by confusing the issues or misleading the jury. Over and above these specific guidelines regarding expert witnesses, there is the well-established general rule that the issue of credibility is the sole province of the jury. "It is hornbook law that the credibility of a witness and the weight to be given his testimony rests exclusively with the jury."

In addition to these broad rules, some jurisdictions have adopted the more stringent Frye test, ${ }^{11}$ which permits expert testimony only where the trial court has found that the scientific principle or discovery underlying the testimony is "sufficiently established to have gained general acceptance in the particular field in which it belongs." 12

Challenges to expert testimony
As noted in Table 4, expert testimony is challenged on several grounds. Overall, the pattern of response by these appellate courts favors admission of testimony that claims that a particular child exhibits signs of sexual abuse or offers general characteristics of sexually abused children. On the other hand, specific syndrome testimony (most often CSAAS) is not usually admitted (33.3\%) when challenged, nor is testi- 


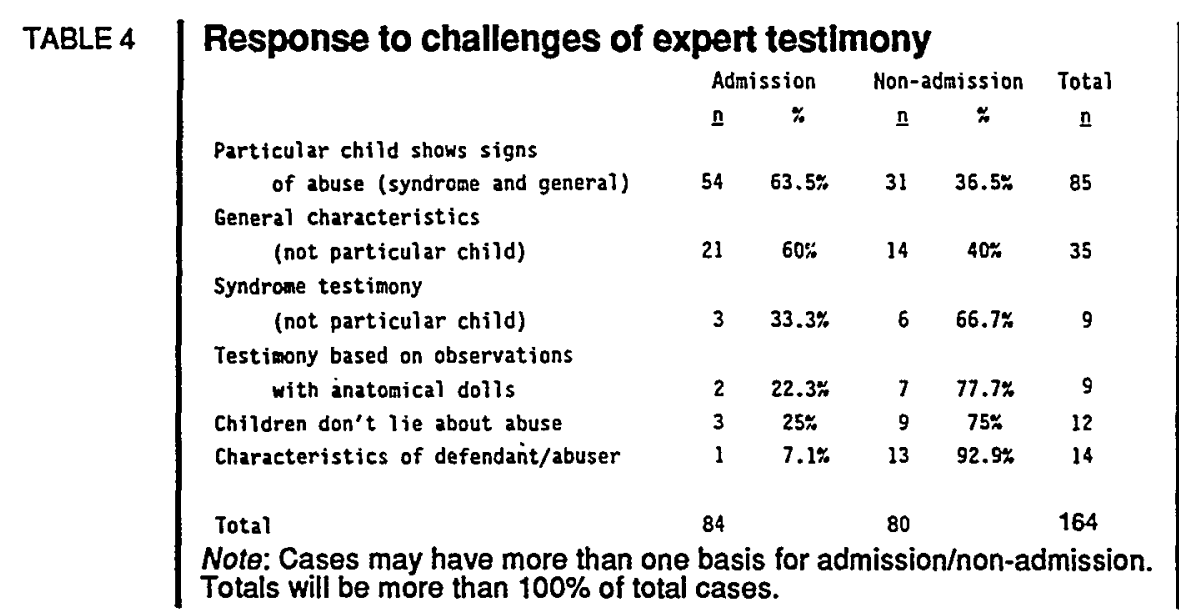

Character- The largest number of challenges to expert testimony are istics of directed at testimony that matches behavioral characteristics sexual abuse applied to a particular of sexually abused children to a particular child. However, most of these appellate courts concluded that this testimony child

mony based on observations with anatomical dolls $(28.6 \%) .^{13}$ Courts are particularly disapproving of testimony that children don't lie about abuse (25\% admission) and are adamantly opposed to testimony that offers characteristics of abusers (7.1\% admission). was properly admitted. The single most important concern of the courts that rejected this testimony was not the accuracy of the testimony or the qualifications of the experts, but that the experts had been too conclusory about a particular child witness telling the truth (see Table 5).

The language of their reasoning varies, but the accepted argument is that expert testimony may not be admitted to "tell the jury who is correct or incorrect, who is lying and who is truthful."14 Other courts express this testimony as a contradiction to Federal Rule 702, since an expert's conclusory opinion is of no assistance to the trier of fact. ${ }^{15}$ 
TABLE 5

\section{Reasons for exclusion of expert testimony}

Reasons

1. Inappropriate support of child's credibility

2. Inappropriately defines characteristics of defendant 13

3. Not helpful/irrelevant

4. Ciaim that "children don't iie" usurps jury function

5. Anatomical dolls not scientifically accepted 7

6. Syndrome not accepted in scientific community 3

7. Syndrome testimony not allowed to prove abuse occurred 3

8. Too prejudicial

Note: Some courts offer more than one reason for exclusion.

The majority of courts, however, allow the expert's testimony, generally stating that it is within the trial court's discretion or that the testimony is helpful. The Supreme Court of Hawaii, the first court to allow this testimony, explained that the expert's opinion regarding the complainant's credibility logically followed from his testimony about the behavior of sexually abused children. Therefore, the testimony respecting the credibility of the complainant "cannot be considered to be substantially more prejudicial than the testimony which led to the conclusion."'16

General Courts admit or exclude testimony limited to a description of characteristics of sexually abused children general characteristics of sexually abused children more often on rebuttal than direct testimony (nine admissions on direct, 12 on rebuttal). This most often occurs when a child's testimony is inconsistent and the expert is called upon to recite that characteristics of inconsistency and denial are common to sexually abused children.

A few appellate courts believe it is more acceptable to admit testimony on general characteristics not applied to a particular child. "While general characteristics testimony may merely inform jurors that commonly held assumptions are not necessarily accurate and allow them to fairly judge credibility, courts have found that when the expert testifies as to the particular child's characteristics or credibility, there is an 
Syndrome testimony undue risk of influencing the jury's independent credibility determination."

These appellate courts are less likely to admit testimony about the behavior of sexually abused children that is specifically titled "child sex abuse accommodation syndrome" (CSAAS) or some version of this title than they are a more flexible list of descriptors with no title. Some courts challenge the scientific reliability of the syndrome on the basis that it is not recognized as a diagnostic category by the American Psychiatric Association or the American Psychological Association. As the court observed in Sara M.:

The Third District concluded the evidence adduced at the jurisdictional hearing failed to meet the Kelly-Frye Standard. The psychologists testified the syndrome is neither included in the Diagnostic and Statistical Manual of Mental Disorders (DSM-III-R) of the American Psychiatric Association nor recognized by the American Psychological Association or other professional organizations. The psychologists described the syndrome as being in the beginning stages of development and acceptance..$^{18}$

Although the American Psychiatric Association's diagnostic system does not recognize the CSAAS or any other diagnostic profile of the sexually abused child, the DSM-III- $\dot{R}$ does recognize post-traumatic stress disorder (PTSD), and at least one court made this distinction in allowing testimony labeled PTSD about a child's reluctance to admit that sexual abuse had occurred. ${ }^{19}$

And yet, some courts do not seem troubled by this lack of acceptance in the relevant scientific community and readily accept syndrome testimony. ${ }^{20}$

Testimony

When directly challenged on this issue, most of these appel-

based on observations with anatomical dolls late courts (two admissions, seven exclusions) refuse to admit testimony that a child's play with anatomical dolls reveals evidence of sexual abuse. This technique, widely used by therapists to aid in assessing whether a child has been sexually abused, is sometimes challenged under the Frye rule as a 
Children never lie about sex abuse new scientific principle not "sufficiently established to have gained general acceptance in the particular field in which it belongs. "21 The court in In re Amber $B .^{22}$ reversed a dependency adjudication based on dolls-assisted testimony, arguing that "The purpose [of the California version] of the Frye rule is to prevent factfinders from being misled by the 'aura of infallibility' that may surround unproven scientific methods."

Most of these appellate courts reject testimony that children don't lie about sex abuse (three admissions, eight exclusions). Some reason that this testimony is conclusory as to the credibility of the child and therefore invades the province of the trier of fact. In People v. Snook ${ }^{23}$ the social worker expert testified that "general attitudes, accepted attitudes as far as the literature concerning child abuse is that children tend not to fabricate stories of sexual abuse and in giving reports tend to reproduce their experiences." Even this qualified statement was considered invasive of the jury's role.

In more recent cases, testimony of this kind is uncommon. Presumably experts have learned that this testimony will be unacceptable. Testimony that may be acceptable, however, is that children of a particular age lack the capacity to relate incidents of sexual abuse if they have not experienced them. ${ }^{24}$

Characteris- Courts are adamant in their refusal to admit testimony regardtics of defen- ing the characteristics of sexual abusers on the grounds that it dant/abuser is too prejudicial to the defendant (92.9\%). In State v. Maule ${ }^{25}$ the court rejected testimony that most child abuse cases involve biological fathers because the testimony was not intended to explain sexual abuse so much as to implicate the defendant.

The rebuttal While many of these appellate courts are reluctant to allow exception expert testimony offered affirmatively, they often willingly and even enthusiastically admit expert testimony to rehabilitate the credibility of the witness who has been attacked by the defense. Twenty-seven courts admitted expert testimony 
on rebuttal, while only seven rejected it (see Table 6). Courts that reject affirmative testimony sometimes express in dicta that they would have allowed it for the purpose of rehabilitating the child witness. Some courts find that expert opinion is inappropriate when it goes to witness credibility if the witness's credibility has not been attacked or put in issue. It will therefore be excluded when ". . . there is insufficient evidence that the victim's character for truthfulness had been directly attacked by the defense."2s

\section{TABLE 6}

$\mid \begin{aligned} & \text { Pattern of admission of rebuttal tes } \\ & \text { Direct testimony } \\ & \text { Rebuttal testimony } \\ & \text { Note: } X^{2}(1, N=164)=13.64, p<.001 \text {. }\end{aligned}$

$\begin{array}{cc}\text { Admit } & \\ \underline{n} & \text { Exclude } \\ 57 & \underline{\mathbf{n}} \\ 27 & 73 \\ & 7\end{array}$

While there is an element of fair play in allowing expert testimony when the child's credibility has been attacked, there are several problems with how these appellate courts handle the rebuttal exception. They allow expert witness testimony on recantation, which associates the child's behavior with a syndrome used to diagnose sexual abuse, and opportunity for rebuttal becomes an open window through which all kinds of testimony not allowed on direct testimony is thrown.

Recantation The typical rebuttal situation occurs when the defense points out that the child delayed, sometimes for months or even years, in telling about the alleged incident of abuse, or that the child recanted regarding the original accusation of abuse. For example, in State $v$. Middleton ${ }^{27}$ a 14-year-old girl reported that her father had raped her. Within one week she made consistent reports to her mother's friend, a Children's Services worker, a doctor, the police, and the grand jury. Six weeks later she recanted in front of her mother, the father's attorney and another witness. 
When evidence of the child's change of story was brought forth at trial, the expert was then allowed to explain this supposedly incomprehensible behavior by testifying that a common characteristic of sexually abused children is denial following an allegation of sexual abuse, presumably out of fear of the abuser. The Middleton court stated on appeal:

If a complaining witness in a burglary trial, after making the initial report, denied several times before testifying at trial that the crime had happened, the jury would have good reason to doubt seriously her credibility at any time. However, in this instance we are concerned with a child who states she has been the victim of sexual abuse by a member of her family. The experts testified that in this situation the young victim often feels guilty about testifying against someone she loves and wonders if she is doing the right thing ... Explaining this bizarre behavior by identifying its emotional antecedents could help the jury better assess the witness' credibility. ${ }^{28}$

Although there is an element of fairness in allowing the expert to counter charges by the defense that recantation indicates lying, the anomaly is that recantation is presented as a characteristic of a sexually abused child, thereby not just convincing the jury that this kind of delay for a child is explainable (as it could be by other theories, as noted in part four), but that it is a characteristic of a sexually abused child. This provides a form of "linkage" that, it could be argued, is highly prejudicial.

Perhaps even more problematical is that the expert's testimony is often not limited to the fact of recantation. In Allison v. State ${ }^{20}$ the child witness was not accused of recantation, but rather of fact complicity with her mother in creating the story. The court then allowed the experts to bring in a very wide range of testimony, with no regard to its reliability, that had little to do with complicity.

In People v. Gray ${ }^{30}$ the nine-year-old child was initially reluctant to disclose the alleged acts of lewd behavior perpetrated by her stepfather and was initially inconsistent in her 
account, naming a stranger, not her stepfather. The expert witness was permitted to testify that "there are certain behavioral traits seen in molestation victims; i.e., delayed reporting, fear of disclosure, accommodation in the sense of outward affection toward an adult a child also fears, and increased likelihood of immediately reporting a stranger rather than a family member. ${ }^{.31}$ In this case the allegation was brought by the girl's father in the course of a child support battle, while the girl's mother reported that the girl had a very good relationship with the stepfather and had shown no signs of emotional distress.

Civil v. Appellate courts in some jurisdictions argue that there should criminal be a more relaxed standard for the acceptance of expert testimony in civil cases, since the constitutional rights of the defendant are not at stake. In one New York custody case, the court observed: ". . . . an overriding point to remember is that it is . . . appropriate to err on the side of admissibility rather than inadmissibility . . a criminal case might require the opposite caution and that the defendant not bear the burden of the effect of unreliability." ${ }^{32}$

The appellate court decisions dealing with civil cases in this study display a similar rate of admission (57.15\% admission for civil, $58.65 \%$ for criminal) as the criminal cases. However, the smaller number of civil cases on appeal in this study make this comparison difficult. The disparity in numbers more likely reflects the higher rate of criminal over civil appeals, not the fact that experts are used less frequently in civil cases.

The courts' responses to the experts' qualifications
There were 11 challenges to the qualifications of the experts testifying; all challenged social workers. Social workers as expert witnesses are a relatively new phenomenon in courtrooms. In six of the appellate court decisions in our sample, the qualifications of the social worker are the only issue on appeal, and in five they are only one of the issues on appeal. 
In only two cases did the challenges succeed in reversing the conviction, and in both of these cases the issue was not testimony about the characteristics of sexually abused children. In State v. Maule ${ }^{33}$ the testimony was about the characteristics of sexual abusers, and the court found that no expertise was established. In the second reversal, both a social worker and a policeman testified as to the veracity of the child. The court reasoned that the trial court had not qualified them as expert witnesses, and that as lay witnesses they could testify only as to events they had witnessed. ${ }^{34}$

The majority of the decisions, however, are accepting of and even enthusiastic about social workers as expert witnesses. As the court observed in Brewington v. State, "35 "Appellant's object is tantamount to asserting that on the issue of how a watch works one would have to call a chemical engineer as opposed to a watchmaker."

In citing the qualifications required for an expert witness testifying in this area, the courts mentioned experience far more often than any other factor (11 references). Education in the field of social work was second (six), while training in the area of sexual abuse was noted by only four courts.

\section{Professional concerns about expert testimony regarding the characteristics of sexually abused children}

The data in this study demonstrate that these appellate courts are concerned with the form in which the expert testimony is presented-i.e., not presented as a specific syndrome, or offered on rebuttal rather than affirmatively-but are reluctant to look beyond the form to examine critically the content of the testimony or the standing of this diagnostic tool within its professional community. The data also indicate that courts are unconcerned about scientific training and are willing to accept the testimony of expert witnesses as long as they have 
had significant clinical experience. They do not question the relationship of the expert with the child.

The reluctance of most of these appellate court judges to go beyond the form of the testimony may indicate their lack of knowledge about social science research. Hafemeister and Melton, ${ }^{36}$ in a study of the impact of social science research on the judiciary, found that "with the exception of a few judges who 'specialize' in cases involving scientific expertise, reliance on social science is still largely a 'liberal' practice of judges who have an expansive view of the judiciary's role in shaping legal doctrine and protecting disenfranchised groups." This finding may help to explain the reluctance of appellate court judges in this study to examine critically the scientific validity of the behavioral characteristics presented by the experts in these cases.

The behavioral characteristics of sexually abused children
The American Psychiatric Association does not include the sexually abused child syndrome in its diagnostic manual, the $D S M-I I I-R$. This fact was noted by three appellate courts in their reason for excluding the expert's testimony (see Table 5). This omission reflects the controversy in the clinical community regarding the validity of a universal symptomology of sexual abuse. As one author writes:

It is impossible to make a general statement about the effects of sexual abuse on children. Children react differently to different situations depending on a number of variables that may be operating at the time of occurrence. . . . children who are sexually abused are not special children with special characteristics: they are not victims of one particular offense, nor do they sustain identical injuries. Their role in the abusive situation, their disclosure of the incident, their relationship to the perpetrator, and their reactions, both long- and short-term, all differ. ${ }^{37}$

In fact, the original intent of classifying the behavioral characteristics of sexually abused children was not to test the child's credibility, but to aid the therapist in providing appropriate treatment. Roland Summit, who is credited with formulating the child sexual abuse accommodation syndrome, 


\begin{abstract}
7
stated explicitly that his goal was not to formulate a sex abuse "test"; rather,

[the] purpose of this paper then, is to provide a vehicle for more sensitive, more therapeutic response to legitimate victims of child sexual abuse and to invite more active, more effective clinical advocacy for the child within the family and within the systems of child protection and criminal justice ${ }^{38}$ (p. 177).
\end{abstract}

The appellate courts in this study are somewhat more critical of the scientific validity of testimony based in part on the use of anatomical dolls, with seven courts citing this as a reason for excluding expert testimony (see Table 5). The use of anatomical dolls by the experts to elicit the child's testimony was specifically noted in a number of cases in this study (23).

The widespread use of sexually anatomically correct dolls by therapists is currently under question in the scientific community. White ${ }^{39}$ and Boat and Everson ${ }^{40}$ found that the dolls stimulated demonstrations of sexual abuse with nonabused children, and Levy ${ }^{41}$ maintains that there is neither a theoretical nor an empirical basis for drawing any conclusion about what a given child's play with the dolls means. In addition, Levy maintains that because the dolls purport to be a scientific demonstration, it establishes a false "aura of infallibility."

Again (as with the child sex abuse accommodation syndrome), the use of anatomically correct dolls may be appropriate as one of the tests used to examine children for the purposes of therapy, while falling short of the scientific reliability required for legal fact-finding. ${ }^{42}$

The experts As described in this study, almost all of the experts (86.7\%) interviewed the children. A majority (68.8\%) examined them sufficiently to claim that a particular child exhibited characteristics of a sexually abused child. A large group (45.9\%) among those who interviewed the child treated the child as well. This study identifies the great majority of these experts 
as therapists, not research scientists or criminal investigators (see Table 3).

Garbarino et al. have criticized the use of therapists to investigate a child's credibility, claiming that a therapeutic approach is conducive to eliciting a response and to dealing with the subjective reality of the child, but not to determining credibility. One court in this study $y^{43}$ considered the testimony of expert witness Roland Summit on the CSAAS reversible error, arguing:

On the one hand is the need to care for and treat an abused child and the need as a treatment device to accept as true his report, whether truthful or not; and on the other hand the preservation of the constitutional right to presumption of innocence in a criminal case."

The neutrality of the expert is a concern for the professional community as well. The APA Ethical Principles warn psychologists to "avoid relationships that limit their objectivity or create a conflict of interest." ${ }^{45}$ Although not noted by any appellate court in this study, the fact that many of these experts were acting as therapists for the child they were testifying about could be seen as breach of their professional neutrality. According to this study, only $13.3 \%$ had no contact with the child at all.

The controversy within the scientific and clinical community suggests that the therapist carries more influence as an expert, and is more persuasive to the jury, than is justified by the level of acceptance of this sort of evidence in his or her professional community. The response of the courts in this study indicates that there is a critical gulf between the scientific community and the judiciary. Judges are not willing and probably not able to critically evaluate the appropriate role of the expert or the reliability of the testimony offered. 


\section{Alternative expert opinions}

Although the appropriateness of expert testimony on the behavioral characteristics of sexually abused children may be both legally and scientifically questioned, there may be a valid role for a different kind of expert and a different kind of testimony based on scientific knowledge about the capabilities of child witnesses. The trend is to introduce a presumption of competence for children as witnesses ${ }^{46}$ The American Bar Association's National Legal Resource Center for Child Advocacy and Protection has proposed rules that would require the trier of fact (judge or jury) to evaluate a child's testimony as it would any testimony. This sometimes presents problems for the trier of fact, who must evaluate the credibility of a witness whose testimony may be inconsistent, incomplete, and easily shaken upon cross-examination.

There is now a fairly large and growing body of scientific literature on the subject of abilities of children as eyewitnesses, not just in sex abuse cases, but under all circumstances. ${ }^{47}$ This research presents a complex picture of the child witness, who is not simply a miniature adult, but has strengths and weaknesses that change over time.

The studies have the advantage of being controlled experiments performed by research scientists rather than clinical observations made by clinicians. The experiments trace the abilities of children through their developmental phases and define their abilities at different ages. There are some contradictory findings among the researchers, and many questions are supported by only fragmentary research. And, of course, the experimental settings cannot reproduce the trauma of witnessing a crime or of being the victim of a crime. Nevertheless, there are several areas of research findings that could provide guidance to the trier of fact who is attempting to assess the testimony of a child witness. 
This guidance would not be as prejudicial to the alleged abuser as testimony regarding the characteristics of the abused child, since it does not deal with the fact of abuse and does not focus on a particular child. In fact, the expert would not interview the child at all, thereby maintaining scientific neutrality. Instead, this testimony would facilitate a general understanding of a child's testimony, leaving the determination of the child's credibility regarding the fact of abuse squarely with the trier of fact.

Recantation As noted earlier in this article, a major application of the child sex abuse accommodation syndrome and its variations is to provide an explanation of why children often recant their allegations of sexual abuse. By using syndrome characteristics to explain recantations, the act of recanting becomes associated as one of the characteristics of a sexually abused child. There are, however, other explanations for recanting that would facilitate understanding the child witness but not require the trier of fact to conclude that sexual abuse occurred.

For instance, social cognitive theorists have conducted experiments to show that children tell the truth about a particular event depending upon what they expect to happen as a result of the information they offer. In one such experiment $t^{48}$ a trusted male instructor broke a glass and used several different techniques-reward, threat, concern, trick and controlto persuade his three- and five-year-old subjects to conceal his action. The three-year-olds were more likely to report the adult's transgression when the appeal was reward (88.9\%), concern $(77.8 \%)$, or trick $(70 \%)$. In response to a threat, however, $50 \%$ would not reveal the truth. On the other hand, the five-year-olds responded equally to the threat and to the reward, with $37.5 \%$ refusing to report the broken glass. Fiveyear-olds were slightly more likely to report the incident if simply instructed not to tell (50\%) or the appeal involved concern (62.5\%). When the appeal was to trick another experimenter, $87.5 \%$ refused to conceal the truth. 
This experiment suggests that inconsistencies may be caused by the procedure of the interviewer and that the age of the child is an important factor.

Memory Adults often believe that children's memories are faulty. Research indicates that even children as young as four can present reliable testimony. ${ }^{49}$ There are caveats, however. When asked to remember past events, children recall less than adults. In a study involving an arm-movement game, researchers found that three-year-olds recalled less about the event than six-year-olds, who in turn recalled less than adults. ${ }^{50}$ Children are more likely to recall social encounters that are "particularly salient to children." ${ }^{51}$ However, it was also found that what they did remember was as accurate as what adults remembered. Therefore, the research suggests that when a child does not have complete recall of an event, it does not mean that the trier of fact should dismiss what he does recall.

Suggestibility The question of children's suggestibility is a sensitive one for the courts. Until the recent imperative of child sex abuse cases, the courts called upon children under ten as witnesses only as a last resort. Researchers are actively studying this issue, ${ }^{52}$ and although there are some disagreements, these studies indicate that in some situations children under ten are more suggestible to various kinds of suggestions than adults. Children also, more than aduits, do not like to admit that they do not know something. When faced with a photo lineup in which the target, a photo of a person they know well, does not appear, $71 \%$ of all children age three to eight made an identification rather than rejecting the lineup, even though they had been told the correct photo might not be there. ${ }^{53}$

Researchers have learned that because children remember less on deliberate recall, they are more dependent upon verbal and nonverbal probings. This provides opportunities for intentional or unintentional suggestions to influence their memory. In addition, children know less about their own 
memory, are less aware of what they do or do not remember, and are more susceptible to post-suggestion events. ${ }^{34}$

Generally, it is agreed that by the age of ten or eleven children are no more vulnerable than adults to misleading or incorrect information. ${ }^{5 s}$ There is controversy about children between six and ten years old. Some research indicates that they are not more susceptible to accepting misinformation than adults, and other research finds that they are. Children under seven are particularly vulnerable to misinformation about peripheral facts but are more reliable on central events. ${ }^{36}$ Preschoolers are found to be very influenced by the authority of the adult questioning them.

Lying Research about children's lies is proceeding in two tracks. One track investigates deliberate falsehoods, and the other examines the role of fantasy in the child's conscious life.

a. Deliberate While courts are unwilling to admit expert testimony that lies concludes that children never lie about sexual abuse, there is a legitimate area of testimony that would be helpful to the trier of fact regarding the patterns of children's lies at different ages and how these patterns may differ from adults'.

Several recent studies suggest that children can deliberately lie at a much earlier age than believed by most adults. ${ }^{57}$ One study ${ }^{\text {ss }}$ found that three-and-a-half to four-year-old preschool children may lie to protect someone they like from punishment. The children were divided into two groups: those who already knew and liked the adult (a "mentor" with whom they had formed a bond) and those to whom the adult was a stranger. Almost half the children lied to protect their mentor; all the children to whom the adult was a stranger told the truth. In other studies, Ceci has identified motives of personal aggrandizement, protecting a loved one, avoiding embarrassment, sustaining a game, and conforming to a stereotype in the lies of very young children. ${ }^{59}$ These studies indicate that children lie for many of the same reasons that adults lie. 
b. Fantasy While there have recently been robust research efforts in the areas of suggestibility and memory, the investigation of childhood fantasies has been lagging. Fantasy becomes an issue in child sex abuse cases particularly when children testify about ritual abuse or satanic cults.

Freud and Piaget both raised serious questions about the ability of young children to separate fact from fantasy. Freud did not claim that preschool-age children believe their fantasies are real, but he did suggest that their tendency to fantasize reduces their reliability. "The untruthworthiness of the assertions of children is due to the predominance of their imagination, just as the untrustworthiness of the assertions of grown-up people is due to the predominance of their prejudices." $"$

Freud also introduced the "seduction theory," which posited that the stories his women patients told him of childhood sexual abuse, often perpetrated by their fathers, were memories of childhood fantasies rather than memories of actual childhood experiences. ${ }^{61}$ This has been countered by contemporary critics, most notably Masson, ${ }^{62}$ who claims that Freud refused to recognize the prevalence of intrafamilial sexual abuse during his time.

Piaget did not identify childhood sexual fantasies. However, he was more pessimistic than Freud about the ability of a child to separate fact and fantasy. He believed that a child has difficulty separating fact and fantasy throughout his whole early childhood. "The child's mind is full of these 'ludistic' (pretend play) tendencies up to the age of 7-8, which means before that age it is very difficult for him to distinguish the truth." 63

Where do contemporary researchers stand on Freud's and Piaget's theories? It is fair to say that with regard to Freud's seduction theory and Piaget's claim that children cannot separate fact from fantasy before the age of seven, the scientific 
community would not proffer the general approval required by the Frye test. On the other hand, there is not a large body of experimental research to counter these two highly influential theorists. ${ }^{64}$ Freud's clinical observations resist experimental study, and no empirical studies have challenged his claims of sexual fantasies in early childhood. Many researchers, however, have tested Piaget's claims. The study of children's play, involving fantasy and make-believe, has received a great deal of attention. There is a consensus that fantasizing is a cognitive ability that develops gradually from around 18 months throughout the early school years. Although researchers do not believe that young children are as egocentric as Piaget suggested, they are still often said to be less able than adults to clearly separate subjective and objective experiences. Between the ages of three and six, researchers believe, the child's grasp of the difference between pretend and not-pretend develops into a conscious distinction. ${ }^{65}$

\section{Conclusion}

Expert testimony in cases involving sexually abused children is particularly powerful, since there is often no other evidence aside from the testimony of the child. This examination of 122 appellate court decisions, both civil and criminal, reveals that most of these courts are willing to admit testimony regarding the characteristics of sexually abused children, particularly on rebuttal, even when it is applied to a particular child. The expert testimony put forth to describe the behavioral characteristics, as described in these appellate opinions, includes a very wide range of descriptors that are often contradictory in nature and many of which could be symptoms of any disturbed child. Nonetheless, few of these courts question the content of the scientific basis of the testimony, and even fewer question the credentials of the experts or their relationship with the child. Those appellate courts that do reject the syndrome most often do so under the evi- 
dentiary rule that this testimony goes to the issue of the child's credibility, which can be determined only by the trier of fact.

This article demonstrates that there is a wide gulf between the scientific/clinical community and the judiciary regarding the content of behavioral syndrome testimony and the role of the expert. While these appellate courts are reluctant to look beyond the form to critically examine the content, the clinical and scientific communities are by no means convinced of the scientific validity of the content, particularly outside the context of therapy. While the appellate courts give the experts their complete approval, the clinical community is likely to question the conflict of role between subjective therapist and objective expert.

This study suggests other types of expert testimony that could be helpful to a trier of fact without being highly prejudicial to the defendant in criminal cases or to the suspected abuser in civil cases. This testimony is directed to the capabilities of child witnesses, not to the credibility of a particular child. A growing body of scientific research performed in controlled experiments is beginning to uncover both the strengths and weaknesses of the developing abilities of children as eyewitnesses. Expert testimony discussing the current state of knowledge regarding children's willingness to recall, memory, and suggestibility would help the trier of fact evaluate a child's testimony without addressing the fact of sexual abuse and without reference to a particular child.

Notes 1. There is another body of cases in which expert testimony is challenged as hearsay testimony. These cases are not included in this study, since this testimony is technically lay, not expert, witness testimony and the witnesses challenged include mothers, teachers, and other non-experts.

2. Legal scholars are also divided on the admissibility of expert witness testimony in child sex abuse cases. Representative of those who 
argue that testimony about the behavioral characteristics of sexually abused children should be allowed in some form include: Myers, Bays, Becker, Berliner, Corwin \& Saywitz, Expert Testimony in Child Sexual Abuse Litigation, 68 Neb. L. Rev. 100 (1989). Note, Expert Testimony in Child Sexual Abuse Prosecutions: A Spectrum of Uses, 68 B.U.L. Rev. 155 (1988). Note, Syndrome Testimony in Child Abuse Prosecutions: The Wave of the Future? 8 St. Louis U. Pub. L. Rev. 207 (1989). Note, The Admissibility of "Child Sexual Abuse Accommodation Syndrome" in California Courts, 17 Pac. L.J. 1361 (1986).

For arguments opposing the admission of the syndrome see: Levy, Using "Scientific". Testimony to Prove Child Sexual Abuse, 23 Family Law Quarterly 383 (1989). Note, the Unreliability of Expert Testimony on the Typical Characteristics of Sexual Abuse Victims, 74 Geo. L.J. 429 (1985). For a position similar to this article, which advocates the use of experts for other purposes, i.e., developmental information regarding memory and recall, see: McCord, Expert Psychological Testimony about Child Complainants in Sexual Abuse Prosecutions: A Foray into the Admissibility of Novel Psychological Evidence, 77 J. Crim. L. \& Criminology 1 (1986).

3. See In re Sara M., 194 Cal. App.3d 585 (Cal. 1987); People v. Roscoe, 168 Cal. App. 1093 (Cal. 1985).

4. Allison v. State, 346 S.E.2d 380 (Ga. 1986) revsd. 353 S.E.2d 805 (Ga. 1987).

Bostic v. State, 772 P.2d 1089 (Ala. 1989).

Brady v. State, 540 N.E.2d 59 (Ind. App. 1989).

Brewington v. State, 702 S.W.2d 312 (Tex. 1986).

Brown v. State, 523 S.2d 729 (Fla. App. 1988).

Brown v. State, 756 S.W.2d 793 (Tex. App. 1988).

Commonwealth v. Baldwin, 502 A.2d 253 (Pa. Super. 1985).

Commonwealth v. Emge, 553 A.2d 74 (Pa. Super. 1988).

Commonwealth v. Higby, 559 A.2d 939 (Pa. Super. 1989).

Commonwealth v. Lewandowski, 491 N.E.2d 670 (Mass. App. 1986).

Commonwealth v. McNeely, 534 A.2d 778 (Penn. 1987).

Commonwealth v. Smith, 567 A.2d 1080 (Pa. Super. 1989).

Commonwealth v. Seese, 517 A.2d 920 (Penn. 1986).

Craig v. State, 544 A.2d 784 (Md. App. 1988).

Delaware v. Gatta, Slip Opinion Nos. IN68-07-0693, IN86-07-0694 (Sup. Ct., decided Aug. 24, 1987).

Ex Parte Hill, 553 So.2d 1138 (Ala. 1989).

Ex Parte McAllister, 541 So.2d 1104 (Ala. 1989).

Glendening v. State, 536 So.2d 212 (Fla. 1988).

Hall v. State, 692 S.W.2d 769 (Ark. App. 1985).

Hester v. Commonwealth, 734 S.W.2d 457 (Ky. 1987).

In re Amber B., 191 Cal. App.3d 682 (1987). 
In re Cheryl H., 153 Cal. App.3d 1098 (1984).

In re Christine C., 191 Cal. App.3d 676 (1987).

In re Erika R., 563 A.2d 369 (Me. 1989).

In re Sara M., 194 Cal. App.3d 585 (1987).

Jimmerson v. State, 380 S.E.2d 65 (Ga. App. 1989).

Kirkpatrick v. State, 747 S.W.2d 833 (Tex. 1987).

Kruse v. State, 483 So.2d 1383 (Fla. 1986).

Logan v. State, 773 S.W.2d 419 (Ark. 1989).

Matter of E.M., 520 N.Y.S.2d 327 (Fam. Ct. 1987).

Matter of Lucas, 380 S.E.2d 563 (N.C. App. 1989).

Matter of Michael G., 492 N.Y.S.2d 993 (Fam. Ct. 1985).

Matter of Nicole V., 510 N.Y.S.2d 567 (A.D. 1987).

Matter of R.B., 369 N.W.2d 353 (Minn. App. 1985).

Matter of Rinesmith, 376 N.W.2d 139 (Mich. App. 1985).

Matter of Sanchez, 535 N.Y.S.2d 937 (1988).

Matter of Shaune L., 541 N.Y.S.2d 562 (Fam. Ct. 1989).

Miller v. State, 376 S.E.2d 901 (Ga. App. 1988).

Miller v. State, 757 S.W.2d 880 (Tex. App. 1988).

Mims v. State, 500 So.2d 100 (Ala. Cr. App. 1986).

Mitchell v. Commonwealth, 777 S.W.2d 930 (Ky. 1989).

Nelson v. Farrey, 874 F.2d 1222 (7th Cir. 1989).

People v. Badour, 421 N.W.2d 624 (Mich. App. 1988).

People v. Beckley, 409 N.W.2d 759 (Mich. App. 1987).

People v. Benjamin R., 481 N.Y.S.2d 827 (1984).

People v. Bowker, 203 Cal. App.3d 385 (1988).

People v. Bradley, 526 N.E.2d 916 (IIl. App. 1988).

People v. Deninger, 772 P.2d 674 (Colo. App. 1989).

People v. Doss, 782 P.2d 1198 (Colo. App. 1989).

People v. Draper, 389 N.W.2d 89 (Mich. App. 1986).

People v. Garrison, 420 N.W.2d 851 (Mich. App. 1988).

People v. Gillespie, 767 P.2d 778 (Colo. App. 1988).

People v. Gray, 187 Cal. App.3d 213 (Cal. 1986).

People v. Jeff, 251 Cal. Rptr. 135, 204 Cal. App.3d 309 (1988).

People v. Keindl, 502 N.E.2d 577 (N.Y. 1986).

People v. Koon, 724 P.2d 1387 (Colo. 1986).

People v. Leon, 214 Cal. App.3d 925 (1989).

People v. Luna, 204 Cal. App.3d 726 (1988).

People v. Matlock, 395 N.W.2d 274 (Mich. 1986).

People v. Pronovost, 756 P.2d 387 (Colo. 1987).

People v. Reinhardt, 423 N.W.2d 275 (Mich. App. 1988).

People v. Roberts, 738 P.2d 380 (Colo. App. 1986).

People v. Roscoe, 168 Cal. App.3d 1093 (1985).

People v. Sanchez, 208 Cal. App.3d 721 (1989).

People v. Snook, 745 P.2d 647 (Colo. 1987).

Powell v. State, 527 A.2d 276 (Del. 1987).

Rodriguez v. State, 741 P.2d 1200 (Ala. 1987).

Scadden v. State, 732 P.2d 1036 (Wyo. 1987).

Seering v. Dept. of Social Serv., 194 Cal. App.3d 298 (1987).

State v. Baks, 784 P.2d 1126 (Utah 1989). 
State v. Boston, 545 N.E.2d 1220 (Ohio 1989).

State v. Bowman 352 S.E.2d 437 (N.C. 1987).

State v. Busch, 515 So.2d 605 (La. App. 1987).

State v. Butler, 349 S.E.2d 684 (Ga. 1986).

State v. Catsam, 534 A.2d 184 (Vt. 1987).

State v. Clark, 682 P.2d 1339 (Mont. 1984).

State v. Clements, 734 P.2d 1096 (Kan. 1987).

State v. Dunbar, 566 A.2d 970 (Vt. 1989).

State v. Eiler, 762 P.2d 210 (Mont. 1988).

State v. Eldredge, 773 P.2d 29 (Utah 1989).

State v. Fletcher, 368 S.E.2d 633 (N.C. 1988).

State v. French, 760 P.2d 86 (Mont. 1988).

State v. Geyman, 729 P.2d 475 (Mont. 1986).

State v. Gray, 533 So.2d 1242 (La. App. 1987).

State v. Hall, 392 N.W.2d 285 (Minn. App. 1986).

State v. Hansen, 728 P.2d 538 (Ore. 1986).

State v. Harwood, 609 P.2d 1312 (Ore. 1980).

State v. Hester, 760 P.2d 27 (Idaho 1988).

State v. Hicks, 535 A.2d 776 (Vt. 1987).

State v. JCE, 767 P.2d 309 (Mont. 1988).

State v. Jackson, 721 P.2d 232 (Kan. 1986).

State v. Jensen, 432 N.W.2d 913 (Wis. 1988).

State v. Jones, 367 S.E.2d 139 (N.C. App. 1988).

State v. Kim, 645 P.2d 1330 (Haw. 1982).

State v. Lindsey, 720 P.2d 73 (Ariz. 1986).

State v. Logue, 372 N.W.2d 151 (S.D. 1985).

State v. Maule, 667 P.2d 96 (Wash. 1983).

State v. McCoy, 400 N.W.2d 807 (Minn. 1987).

State v. Middleton, 657 P.2d 1215 (Ore. 1983).

State v. Moran, 728 P.2d 248 (Ariz. 1986).

State v. Myers, 359 N.W.2d 604 (Minn. 1984).

State v. Myers, 382 N.W.2d 91 (lowa 1986).

State v. Newman, 784 P.2d 1006 (N.M. App. 1989).

State v. Oliver, 372 S.E.2d 256 (Ga. App. 1988).

State v. Parks, 386 S.E.2d 748 (N.C. App. 1989).

State v. Reser, 767 P.2d 1277 (Kan. 1989).

State v. Risdal, 404 N.W.2d 130 (lowa 1987).

State v. Romero, 432 N.W.2d 899 (Wis. 1988).

State v. Sorenson, 421 N.W.2d 77 (Wis. 1988).

State v. Spigarolo, 556 A.2d 112 (Conn. 1989).

State v. Timperio, 528 N.E.2d 594 (Ohio App. 1987).

Stephens v. State, 774 P.2d 60 (Wyo. 1989).

Tingle v. State, 536 So.2d 202 (Fla. 1988).

Townsend v. State, 734 P.2d 705 (Nev. 1987).

U.S. v. Azure, 801 F.2d 336 (8th Cir. 1986).

U.S. v. Binder, 769 F.2d 595 (9th Cir. 1985). 
U.S. v. Shaw, 824 F.2d 601 (8th Cir. 1987). Utah v. Rimmasch, 775 P.2d 388 (Utah 1989). Utah v. Van Matre, 777 P.2d 459 (Utah 1989).

Ward v. State, 519 S.2d 1082 (Fla. App. 1988).

Weeks v. State, 370 S.E.2d 344 (Ga. App. 1988).

Westbrook v. State, 368 S.E.2d 131 (Ga. App. 1988).

Wheat v. State, 527 A.2d 269 (Del. 1987).

Wilkerson v. Pearson, 509 A.2d 818 (N.J. Super. 1985).

5. Summit, The Child Sexual Abuse Accommodation Syndrome, 7 CHIID ABUSE AND NEGLECT (1983) at 177.

6. State v. Reser, 767 P.2d 1277 (Kan. 1989); Matter of E.M., 520 N.Y.S.2d 327 (N.Y. 1987); Townsend v. State, 734 P.2d 705 (Nev. 1987); State v. Catsam, 534 A.2d 184 (Vt. 1987).

7. State v. Myers, 359 N.W.2d 604 (Minn. 1984).

8. 519 S.W.2d 1082 (Fla. 1988).

9. F.R. Evidence 702.

10. United States v. Rosenberg, 108 F.Supp. 798, 806 (S.D.N.Y. 1952, aff'd 200 F.2d 666 (2d Cir. 1952).

11. See Frye v. U.S., 293 F. 1013 (D.C. Cir. 1923).

12. Id. at 1014 .

13. It should be noted that syndrome testimony and anatomical doll observations most often go unchallenged.

14. U.S. v. Azure, 801 F.2d 336 (8th Cir. 1986).

15. State v. Moran, 728 P.2d 248 (Ariz. 1986).

16. State v. Kim, 645 P.2d 1330 (Haw. 1982).

17. See supra note 15.

18. See supra note 3 , at 605 .

19. Kruse v. State, 483 So.2d 1383 (Fla. 1986).

20. See, e.g., People v. Luna, 204 Cal. App.3d 726 (Cal. 1988); People v. Gray, 187 Cal. App.3d 213 (Cal. 1986).

21. See supra note 11, at 1013.

22. 191 Cal. App.3d 682, 686 (Cal. 1987).

23. 745 P.2d 647, 648 (Colo. 1987). 
24. See, e.g., Brown v. State, 523 S.2d 729 (Fla. App. 1988); State v. Butler, 349 S.E.2d 684 (Ga. 1986).

25. . 667 P.2d 96 (Wash. 1983).

26. See supra note 23 , at 647 .

27. 657 P.2d 1215 (Or. 1983).

28. Id. at 1219-1220.

29. 346 S.E.2d 380 (Ga. 1986), revsd. 353 S.E.2d 805 (Ga. 1987).

30. 187 Cal. App.3d 213 (Cal. 1986).

31. Id. at 221.

32. Matter of E.M., 520 N.Y.S.2d 327, 332 (1987).

33. See supra note 25 .

34. See State v. Romero, 432 N.W.2d 899 (Wis. 1988).

35. 702 S.W.2d 312 (Tex. 1986) at 318.

36. Hafemeister \& Melton, The Influence of Social Science Research on the Judiciary, in REFORMING TiHE LAW (1987) at 55.

37. Rosenfeld, The Clinical Management of Incest and Sexual Abuse of Children, 22 Trauma (1980) at 2-12.

38. Summit, The Child Sexual Abuse Accommodation Syndrome, 7 CHII. A ABUSE AND NEglect (1983) at 177.

39. White, Should Investigators Use of Anatomical Dolls Be Defined by the Court?, 3 JourNal OF INTERPERSONAL VIOLENCE (1988) at 471475.

40. Paper presented at the Society for Research in Child Development Biennial Meeting by B. Boat and M. Everson (1987).

41. Levy, Using "Scientific" Testimony to Prove Child Sexual Abuse, 13 FAMIIY LAW QUARTERLY (Fall 1989) at 383.

42. J. Garbarino \& F. StotT, What Childoren Can Teli Us (1989) at 195.

43. People v. Leon, 214 Cal. App.3d 925 (1989).

44. Id. at 939.

45. Ethical Principles of Psychologists, 36 AMERICAN PsYchologist (1981) at 631. 
46. B. R. DZIECTY \& C. B. SchudSON, ON TRIAI (1989).

47. S. J. Ceci, M. DeSimone, M. B. Putnick \& M. L. Lee, "Motives to Lie." Paper presented at Psychology and Law Conference, Williamsburg, Va. (1990); M. A. EKMAN \& T. EkMAN, WHY KIDS LIE (1989).

48. K. Bussey, "Adult Influence on Children's Eyewitness Reporting." Paper presented at Psychology and Law Conference, Williamsburg, Va. (1990).

49. Cole \& Loftus, The Memory of Children, in CHIIDREN's EyEwITNESS Memory (S. J. Ceci, M. P. Taglia \& D. F. Ross, eds., 1987); Zaragoza, Memory, Suggestibility and Eyewitness Testimony in Children and Adults, in CHILDREN's EYEWITNESS MEMORY.

50. Goodman, Amon \& Hirshman, Child Sexual and Physical Abuse; Children's Testimony, in CHIIDREN's EYEWITNESS MEMORY.

51. Todd \& Perlmutter, Reality Recalled by Preschool Children, in ChIDREN's Memory: New Directions For ChILd DeVElopment, No. 10 (M. Perlmutter, ed., 1980).

52. See, e.g., Cole \& Loftus, supra note 49; Zaragoza, supra note 49; King \& Yuille, Suggestibility and the Child Witness, in CHIIDREN's EyewITNEss MEMORY; Saywitz, Children's Testimony: Age-related Patterns of Memory Errors, in CHILDREN's EYEWITNESS MEMORY.

53. Cole \& Loftus, supra note 49.

54. Brown, Knowing When, Where and How to Remember: A Problem of Metacognition, in ADVANCES IN CHIID DEVELOPMENT AND BEHAVTOR, Vol. 10 (H. W. Reese, ed., 1978); Saywitz, supra note 52.

55. Cole \& Loftus, supra note 49.

56. Id.

57. Ekman, supra note 47; Lewis, Stanger \& Sullivan, Deception in Three-Year-Olds, 25(3) DEVELOPMENTAL PsyCHOLOGY (1989) at 439443.

58. Ceci, DeSimone, Putnick \& Lee, supra note 47.

59. Id.

60. Freud, Two Case Histories, in The Standard Edition of the COMPLETE PSYChological Works OF SigMUNd FreUd, Vol. 10, pp. 102-103 (J. Strachey, ed., 1955) (original work published 1909). 
61. Freud, New Introductory Lectures on Psychoanalysis, in THE STANDARD EDITION OF THE COMPLETE PSYCHOLOGICAL WORKS OF SigMUND FreUd (J. Strachey, ed., 1964) (original work published 1933).

62. Masson, Freud and the Seduction Theory, ThE ATLANTIC MonthLY (Feb. 1984) at 33-60.

63. Piaget, The Child's Conception of the World (1983) at 34 (original work published in 1926).

64. Lindsay \& Johnson, Reality Monitoring and Suggestibility: Children's Ability to Discriminate Among Memories from Different Sources, in CHIDREN's EYEWTINESS MEMORY.

65. Id. 
